\title{
Prognostic markers of canine pyometra
}

\author{
[Marcadores prognósticos na piometra canina] \\ M.C. Sant'Anna, L.G.P. Giordano, K.K.M.C. Flaiban, E.E. Muller, M.I.M. Martins* \\ Universidade Estadual de Londrina - Londrina, PR
}

\begin{abstract}
The pyometra is a disease that affects middle age and elderly female dogs during diestrus. Hormonal, microbiological, biochemical and hematological aspects are well described. However, few studies have evaluated the role of each in the prognosis of canine pyometra. The aim of this study was to identify markers associated with clinical worsening of dogs with pyometra. We prospectively evaluated 80 dogs with pyometra treated surgically. Group 1 consisted of dogs that were discharged within 48 hours after surgery and Group 2 consisted of those who required prolonged hospitalization or died. The findings of hematological, biochemical and blood lactate levels were compared between groups and variables such as bacterial multidrug resistance, systemic inflammatory response syndrome (SIRS), hyperlactatemia and increased creatinine were analyzed through the dispersion of frequencies between groups. Among the variables studied, the presence of SIRS and elevated serum creatinine $>2.5 \mathrm{mg} / \mathrm{mL}$ were effective in predicting the worsening of the disease and can be used as prognostic markers of canine pyometra.
\end{abstract}

Keywords: bitch, endometrial hyperplasia, SIRS, bacterial multidrug resistance, hyperlactatemia

\section{RESUMO}

A piometra é doença que acomete as fêmeas da espécie canina de meia-idade a idosa durante o diestro. Aspectos hormonais, microbiológicos, hematológicos e bioquímicos são bem descritos. Entretanto, são poucos os estudos que avaliam o papel de cada um desses no prognóstico da piometra canina. O objetivo deste estudo foi identificar marcadores associados ao agravamento clínico de cadelas com piometra. Foram avaliadas prospectivamente 80 cadelas com piometra tratadas cirurgicamente. O grupo 1 foi composto por cadelas que receberam alta até 48 horas de pós-operatório, e o grupo 2 por aquelas que necessitaram de internamento prolongado ou morreram. Os achados hematológicos, bioquímicos e os níveis do lactato sanguíneo foram comparados entre os grupos, e variáveis como multirresistência bacteriana, síndrome da resposta inflamatória sistêmica (SIRS), hiperlactatemia e aumento da creatinina foram analisadas por meio da dispersão de frequências entre os grupos. Entre as variáveis estudadas, a presença de SIRS e a elevação da creatinina sérica $>2,5 \mathrm{mg} / \mathrm{mL}$ foram eficazes em predizer $o$ agravamento da doença e podem ser utilizadas como marcadores prognósticos da piometra canina.

Palavras-chave: cadela, hiperplasia endometrial, SIRS, multirresistência bacteriana, hiperlactatemia

\section{INTRODUCTION}

Pyometra is a disease that usually occurs during diestrus in intact adult females. It is characterised by an inflammatory exudate and uterine bacterial colonisation associated with cystic endometrial hyperplasia (CEH) (Johnston et al., 2001).
The haematological and biochemical abnormalities commonly found during the course of the disease are leukocytosis with neutrophilia, hyperglobulinaemia and azotaemia. The azotaemia is secondary to glomerulonephritis by immune complex deposition in the glomerular basement membrane and is aggravated by prerenal azotaemia (Fieni, 2006; Johnson, 2006; Pretzer, 2008).

Recebido em 14 de maio de 2013

Aceito em 19 de fevereiro de 2014

*Autor para correspondência (corresponding author)

E-mail imartins@uel.br 
Systemic inflammatory response syndrome (SIRS) is a clinical manifestation of the organism in response to an initial stimulus severe enough to produce a systemic release of inflammatory mediators. Sepsis is a disease manifested by SIRS of infectious origin (Purvis and Kirby, 1994).

Early recognition of SIRS or sepsis in human and veterinary medicine is important for proper treatment and monitoring of patients (Gebhardt et al., 2009). Critically ill patients with SIRS are more likely to develop multiple organ dysfunction syndrome (MODS), although even those mildly affected may suffer from SIRS and MODS if a secondary stimulus occurs (Fransson, 2003).

Sepsis can raise levels of blood lactate for reasons that are not well defined. It is believed that a combination of factors, such as reduction in tissue oxygenation, hypermetabolism during inflammatory processes and changes in the glycolytic enzyme system are responsible (Gutierrez and Wulf, 1996). According to several authors, the serum lactate can be used as a criterion for prognosis, diagnosis and assessment of treatment response in critically ill patients (Nel et al., 2004; Koliski et al., 2005; Rabelo et al., 2009).

Microbial resistance to antibiotics depends on the frequency of use (Greene, 2006). Although several studies, especially Brazilian ones, have identified high rates of bacterial resistance in canine pyometra, there is little information on the prognostic value of bacterial multidrug resistance in this disease (Weiss et al., 2004; Coggan, 2005; Otto, 2007).

Therefore, the aim of this study was to identify whether SIRS, multidrug-resistant bacteria, haematological and biochemical changes and blood lactate could be used as prognostic markers in dogs with pyometra.

\section{MATERIAL AND METHODS}

The study was approved by the ethics and animal experimentation committee of the State University of Londrina (UEL), and every owner was consulted and informed about all procedures that were to be performed.
Eighty dogs from 17 different breeds were diagnosed with pyometra between May 2010 and August 2011 and followed up during the period of hospitalisation at the Veterinary Hospital (VH) of the State University of Londrina (UEL). The treatment of all animals in the study was ovariohysterectomy (OSH), and the patients were supplemented with antibiotics and fluids as needed. The decision regarding treatment was performed by the emergency team of the $\mathrm{VH}$, and the study group did not influence the choice of antibiotic and/or length of stay.

The diagnosis was based on history, physical examination, presence or not of vulvar discharge, haematology and imaging ( $\mathrm{Rx}$ and/or ultrasound). Clinical examination was performed upon admission, and the following data were collected: heart rate (HR), respiratory frequency (RF) and rectal temperature $(\mathrm{T})$.

The animals were divided into two groups according to clinical evolution: patients that were discharged 48 hours after surgery were allocated to Group 1 (G1), and patients that required hospitalisation exceeding 48 hours or died during the surgical procedure or hospital stay were allocated to Group 2 (G2). A hospital stay of more than 48 hours after the surgical treatment of pyometra usually results from complications or a severely debilitated patient. The period of stay and number of deaths during the study were compiled.

Of the 80 dogs studied, 62 (77.5\%) were placed in G1 and 18 (22.7\%) in G2. The mean body weight of the dogs in G1 was $12 \pm 15 \mathrm{~kg}$, and the mean body weight of the dogs in G2 was $18.25 \pm 10.8 \mathrm{~kg}$. The average age was $6.97 \pm 3.38$ years for $\mathrm{G} 1$ and $8.53 \pm 4.55$ years for $\mathrm{G} 2$.

Blood samples were collected by puncturing the jugular vein after antisepsis. The samples were separated into two tubes, one containing an anticoagulant for haematology and another without anticoagulant for serum separation and subsequent biochemical tests. Immediately after collection, one drop of blood was used for measurement of venous lactate using Accutrend ${ }^{\circledR}$ and BM-Lactate strips (both from Roche Diagnostics ${ }^{\circledR}$, Germany). A new blood sample was collected 24 hours after surgery to repeat the blood lactate test. Blood counts were performed immediately after collection in the Veterinary Clinical Pathology laboratory at VH - UEL. The 
serum was placed in plastic tubes and frozen at $20^{\circ} \mathrm{C}$ in an upright freezer. After the serum was thawed at refrigerator temperature $\left(5^{\circ} \mathrm{C}\right)$, it was used for biochemical tests, thereby minimizing inter-assay variation. Alanine amino transferase (ALT), alkaline phosphatase (AP), blood urea nitrogen (BUN) and creatinine were determined by the kinetic method, whereas the total protein (TP) was determined by the biuret method and the albumin was determined by the colorimetric method using a BS-120 spectrophotometer (Mindray ${ }^{\circledR}$, China).

After removal of the uterus, the contents of the uterine horns were aseptically aspirated with a sterile needle and syringe and sent immediately to the microbiology laboratory of the VH-UEL. Initially the culture was performed on 5\% sheep blood agar (Himedia ${ }^{\circledR}$, Mumbai, India), and the plates were incubated aerobically at $37^{\circ} \mathrm{C}$ for 72 hours. We analysed the micro-organisms isolated by Gram staining, catalase, coagulase, and esculin tests and 6.5\% $\mathrm{NaCl}$ tolerance (Holt et al., 1994). Gram-negative bacteria were placed on MacConkey agar and identified by the Bactray system (Laborclin ${ }^{\circledR}$ Pinhais, Brazil). The susceptibility tests were performed in culture and on Muller Hinton agar (Himedia ${ }^{\circledR}$, Mumbai, India) employing the diffusion method, using the technique of Bauer et al. (1966) to determine the sensitivity and resistance of the isolated bacteria. The following antibiotics were used at the following amounts per disc: amoxicillin $(20 \mu \mathrm{g})$, cephalothin $(30 \mu \mathrm{g})$, ciprofloxacin $(05 \mu \mathrm{g})$,

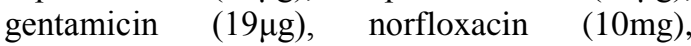
enrofloxacin $(5 \mu \mathrm{g})$ and penicillin (10mg) (Laborclin $^{\circledR}$, Pinhais, Brazil). The results were read by measuring the diameter of the zone of inhibition of microorganism growth. The criteria used for interpretation and concentrations followed the recommendations of the "National Committee for Clinical Laboratory Standards NCCLS" (National..., 1999). Strains resistant to three or more antibiotics were considered multidrug-resistant strains.

Patients were classified as positive for SIRS when they had two or more of the following four criteria: $\mathrm{RR}>20$ breaths per minute, heart rate $>120$ beats per minute, temperature $<38.1$ or $>39.2^{\circ} \mathrm{C}$, total leukocyte count $<6$ or $>16 \mathrm{x}$ $10 / \mathrm{mm}^{3}$ or percentage of band neutrophils $>3 \%$. This test has $97 \%$ sensitivity in diagnosing patients with SIRS and $64 \%$ specificity in classifying patients without SIRS (Hauptman et al., 1997).

Statistical analysis was performed using Minitab 16 (2011) and Epi Info 6.04 (2001). The average values of the variables erythrocytes, packed cell volume (PCV) and haemoglobin level were compared between groups using the Tukey test. The median values of the variables total leukocytes, mature neutrophils, band neutrophils, lymphocytes, eosinophils, monocytes, platelet count, BUN, creatinine, ALT, PA, total protein, albumin, glucose, preoperative lactate and postoperative lactate were compared between the groups using the Mann-Whitney test. For association of the presence of SIRS variables, bacterial multidrug resistance, preoperative hyperlactatemia $(>2.5 \mathrm{mmol} / \mathrm{L})$ and creatinine $>2.5 \mathrm{mg} / \mathrm{dl}$ with prolonged hospitalisation and/or death, the chi-square and Fisher exact test were used. We adopted a significance level of $5 \%$ for all tests. Values below the detection limit for the measurement of lactate $(<0.8 \mathrm{mmol} / \mathrm{l})$ were considered zero for calculations.

\section{RESULTS AND DISCUSSION}

The frequency of the variables SIRS, closed piometra, bacterial multidrug resistance, hyperlactatemia, and preoperative creatinine $>2.5 \mathrm{mg} / \mathrm{dL}$ and their association with prolonged hospitalisation and/or death are shown in Table 1. Of these, the presence of SIRS $(\mathrm{P}=0.031)$ and levels of serum creatinine $>2.5 \mathrm{mg} / \mathrm{dl}(\mathrm{P}<0.001)$ were significantly associated with prolonged hospitalisation and / or death.

Of the 66 cases classified as SIRS positive, 21 (31.8\%) had two of the four criteria, 28 (42.4\%) were positive for three of the four criteria, and 17 (25.8\%) were positive for all four criteria for SIRS diagnosis.

The association of SIRS with morbidity and mortality in this study shows the importance of using these criteria so that supportive treatment can be instituted as soon as possible. In a similar study, Fransson et al. (2007) evaluated 53 bitches with pyometra; 57\% of them were positive for SIRS, and 23\% required a hospital stay exceeding three days. There was a significant association between the presence of SIRS in pyometra and morbidity. However, other studies found no association between the 
presence of SIRS and morbidity and/or mortality in dogs with pyometra (Pelander et al., 2008; Hagman et al., 2009; Hagman, 2011). The apparent difference in these findings is likely due to the different populations studied because the low percentage of dogs that required prolonged hospitalisation or eventually died may have limited this review.

Table 1. Association of the variables SIRS, bacterial multidrug resistance, hyperlactatemia, and preoperative creatinine $>2.5 \mathrm{mg} / \mathrm{dL}$ with extended hospitalisation and/or death by using the chi-square and Fisher tests at a significance level of 5\%, Londrina - PR, 2012

\begin{tabular}{|c|c|c|}
\hline Variables & $\begin{array}{c}\text { Hospitalisation } \\
>48 \mathrm{~h} \text { and/or } \\
\text { death } \\
\text { n/total (\%) }\end{array}$ & $\mathrm{P}$ value \\
\hline \multicolumn{3}{|l|}{ SIRS } \\
\hline Presence & 18/66 (27\%) & $0.031 *$ \\
\hline Absence & $0 / 14$ & \\
\hline \multicolumn{3}{|l|}{ Closed pyometra } \\
\hline Presence & $7 / 26$ (27\%) & 0.710 \\
\hline Absence & $11 / 54(20 \%)$ & \\
\hline \multicolumn{3}{|l|}{ Multidrug } \\
\hline resistance & 3/21 (14\%) & 0.343 \\
\hline Presence & $10 / 38(26 \%)$ & \\
\hline \multicolumn{3}{|l|}{ Absence } \\
\hline \multicolumn{3}{|l|}{ Hyperlactataemia } \\
\hline Presence & 8/37 (22\%) & 0.925 \\
\hline Absence & 10/33 (30\%) & \\
\hline $\begin{array}{l}\text { Creatinine }>2.5 \\
\mathrm{mg} / \mathrm{dl}\end{array}$ & 8/10 (80\%) & $<0.001 *$ \\
\hline Presence & $10 / 70(14 \%)$ & \\
\hline Absence & & \\
\hline
\end{tabular}

* Significant association

In relation to clinical classification of canine pyometra as opened or closed, it is described where the uterine cervix does not drain the contents to the exterior environment and the clinical severity is exacerbated (Johnson, 2006). However, in this study, no difference in prognosis for dogs with opened or closed pyometra was observed, because this parameter didn't show any significant association with cases requiring prolonged hospitalization and / or death $(\mathrm{P}=0.71)$. One possible explanation for this result is that the owners only looked for specialized help after the observation of vaginal discharge, so bitches with supposedly closed pyometra before arrived for treatment only when the cervix was won by intrauterine pressure, being classified during evaluation as opened. In another Brazilian study, Volpato et al. (2012) compared laboratory findings between bitches with opened and closed pyometra, and he did not observe hematological and biochemical differences between groups.

Of the 80 dogs studied, 59 (73\%) were positive for the presence of bacteria in the uterus. E. coli and Streptococcus spp were cultured from 52.5\% (31/59) and $13.6 \%$ (8/59) of the specimens, respectively. The remaining isolates are listed in Table 2. The antibiotics that showed the worst performance against the isolated bacteria in culture were penicillin with $86.4 \%$ (51/59) resistance, cephalothin with 59.3\% (35/59) resistance and enrofloxacin with 23.7\% (14/59) resistance, as seen in Table 3 .

Table 2. Bacteria isolated from uterine secretions of 59/80 dogs with pyometra, Londrina-PR, 2012

\begin{tabular}{lcc} 
Bacteria & $\mathrm{n}$ & $\mathbf{( \% )}$ \\
\hline E. coli & 31 & 52.2 \\
Streptococcus spp & 8 & 13.6 \\
Klebsiella spp & 5 & 8.5 \\
Pseudomonas spp & 4 & 6.8 \\
Staphylococcus spp & 3 & 5.1 \\
E. coli + Klebsiella & 2 & 3.4 \\
spp & & \\
E. coli + & 2 & 3.4 \\
Streptococcus spp & & \\
Salmonella spp & 2 & 3.4 \\
E. coli + & 1 & 1.7 \\
Staphylococcus spp & & \\
Proteus spp & 1 & 1.7 \\
\hline Total & $\mathbf{5 9}$ & $\mathbf{1 0 0}$ \\
\hline
\end{tabular}

The percentage of multidrug-resistant strains was $35.6 \%$ (21/59). This high prevalence of multidrug-resistant strains is likely due to the indiscriminate use of antibiotics in Brazil. In Sweden, Hagman (2004) found that only 8/136 isolates of $E$. coli were resistant to two antibiotics, and there were no cases of multidrug resistance in a four-year study. Siqueira et al. (2008) found that in Brazil, 13.5\% of E. coli strains were multidrug resistant. In this study, multidrug resistance was not important in clinical cases, showing no significant association with morbidity and/or mortality, likely because all patients were treated by OSH, which removed the focus of infection. This parameter may be more relevant in dogs with pyometra that is medically treated. 
Prognostic markers...

Table 3. Profile of bacterial resistance and sensitivity to antibiotics tested on 59 isolates from the uterine contents of 80 dogs with pyometra, Londrina-PR, 2012

\begin{tabular}{lcc}
\hline Antibiotics & Resistance\% (n/total) & Sensitivity\% (n/total) \\
\hline Penicillin & $86.4 \%(51 / 59)$ & $13.6 \%(8 / 59)$ \\
Cephalothin & $59.3 \%(35 / 59)$ & $40.7 \%(24 / 59)$ \\
Enrofloxacin & $23.7 \%(14 / 59)$ & $76.3 \%(45 / 59)$ \\
Ciprofloxacin & $20.3 \%(12 / 59)$ & $79.7 \%(47 / 59)$ \\
Norfloxacin & $13.6 \%(8 / 59)$ & $86.4 \%(51 / 59)$ \\
Amoxicillin & $11.9 \%(7 / 59)$ & $88.1 \%(52 / 59)$ \\
Gentamicin & $10.2 \%(6 / 59)$ & $89.8 \%(53 / 59)$ \\
\hline
\end{tabular}

Although several authors reported that serum lactate may be used for the prognosis, diagnosis and assessment of treatment response in critically ill patients, especially when serial measurements are taken (Lagutchik et al., 1996; Nel et al., 2004; Koliski et al., 2005; Stevenson et al., 2007; Rabelo et al., 2009; Holahan et al., 2010), in this study preoperative hyperlactatemia was not significantly associated with morbidity and / or mortality $(\mathrm{P}=0.93)$, and no significant difference in pre- and postoperative blood lactate levels was found between groups G1 and G2 $(\mathrm{P}=0.35$ and $\mathrm{P}=0.33)$. Hagman et al. (2009) also found no significant correlation between hyperlactatemia and prognosis of this disease, and when cases of pyometra were compared with healthy dogs, the lactate concentrations were similar.

No haematological variable evaluated was significantly different between groups, including the parameters that were used for the classification of SIRS, total leukocytes and neutrophils. These results showed that although tests of erythrocyte and leukocyte levels are useful in diagnosis, they are not reliable for predicting cases of canine pyometra. The haematology results and comparison groups are shown in detail in Table 4.

Table 4. Erythrocyte, packed cell volume (PCV) and haemoglobin concentration values expressed as the mean and standard deviation and compared between groups using the Tukey test, and leukocyte and platelet values expressed as the median and compared between groups using the Mann-Whitney test, with a significance level of 5\%, Londrina - PR, 2012

\begin{tabular}{lccc}
\hline Variable & $\mathrm{G} 1$ & $\mathrm{G} 2$ & P value \\
& mean $\pm \mathrm{SD}$ & Tukey \\
\hline Erythrocyte $\left({\left.\mathrm{x} 10^{6}\right)}\right)$ & $5.85 \pm 1.44$ & $6.14 \pm 1.52$ & 0.453 \\
PCV $(\%)$ & $36.95 \pm 9.52$ & $39.46 \pm 11.11$ & 0.347 \\
Haemoglobin(g/dl) & $11.33 \pm 2.85$ & $11.61 \pm 3.34$ & 0.722 \\
& median & median & P value \\
Total leukocytes $\left(\mathrm{m} / \mathrm{mm}^{3}\right)$ & $21,570(4,150-101,870)$ & $24,785(22,510-41,700)$ & 0.218 \\
Mature neutrophils $\left(\mathrm{m}^{3} / \mathrm{mm}^{3}\right)$ & $16,990(2,142-75,383)$ & $20,058(14,125-34,611)$ & 0.235 \\
Band neutrophils $\left(\mathrm{m} / \mathrm{mm}^{3}\right)$ & $894.8(0-13,243)$ & $2,042.5(0-3,784)$ & 0.347 \\
Lymphocytes $\left(\mathrm{m} / \mathrm{mm}^{3}\right)$ & $2,000(226-12,224)$ & $2,238(548-7,343)$ & 0.482 \\
Platelet count $\left(\mathrm{m} / \mathrm{mm}^{3}\right)$ & 339,000 & 270,000 & 0.067 \\
& $(21,000-960,000)$ & $(24,000-1,027,000)$ & \\
\hline
\end{tabular}

Biochemical evaluation indicated that BUN $(\mathrm{P}=0.001)$, creatinine $(\mathrm{P}=0.001)$ and ALT $(\mathrm{P}=0.038)$ levels were significantly higher in $\mathrm{G} 2$ than G1 (Table 5). However, the ALT values did not increase above the reference values. On the other hand, elevated creatinine above $2.5 \mathrm{mg} / \mathrm{dl}$ was significantly associated with prolonged hospitalisation and/or death
$(\mathrm{P}<0.001)$. Therefore, this parameter was a good indicator of morbidity and mortality in dogs suffering from pyometra. This result conflicts with that of Kuplulu et al. (2009), who concluded that increased BUN and creatinine were the only parameters significantly associated with death cases. 
Table 5. Biochemical parameters of dogs with pyometra expressed as median and compared between groups using the Mann-Whitney test with a significance level of 5\%, Londrina - PR, 2012

\begin{tabular}{lccc}
$\begin{array}{l}\text { Biochemical } \\
\text { parameters }\end{array}$ & $\begin{array}{c}\text { G1 } \\
\text { Mediana } \\
\text { (interval) }\end{array}$ & $\begin{array}{c}\text { G2 } \\
\text { Mediana } \\
\text { (interval) }\end{array}$ & P value \\
\hline BUN (mg/dl) & $31(8-292)$ & $168(28-508)$ & $0.000^{*}$ \\
Creatinine (mg/dl) & $0.85(0.28-2.32)$ & $2.50(0.39-10.2)$ & $0.001^{*}$ \\
ALT (U/L) & $22(4-49)$ & $25(12-59)$ & $0.038^{*}$ \\
AP (U/L) & $230(31-2,573)$ & $267(37-876)$ & 0.469 \\
TP (g/dl) & $9.0(5-14.9)$ & $8.8(5.6-12.6)$ & 0.714 \\
Albumin (g/dl) & $1.9(1-4.3)$ & $2.2(1.1-3.7)$ & 0.244 \\
Glucose (mg/dl) & $100(33-416)$ & $90(28-747)$ & 0.182 \\
Lactate preoperatively (mmol/L) & $2.4(<0.8-5)$ & $2.4(1.2-4.8)$ & 0.350 \\
Lactate postoperative (mmol/L) & $1.4(<0.8-4.8)$ & $1.6(<0.8-4.9)$ & 0.333 \\
\hline
\end{tabular}

ALT: alanine amino transferase, AP: alkaline phosphatase, TP: Total Protein, BUN: blood urea nitrogen.

* Significant difference

\section{CONCLUSIONS}

Among the variables studied, SIRS and the serum creatinine level can be used as prognostic markers of canine pyometra because the presence of SIRS and creatinine levels above $2.5 \mathrm{mg} / \mathrm{dl}$ were associated with morbidity and mortality in the cases studied. Moreover, hyperlactatemia and the presence of multidrug-resistant strains did not interfere with the outcome of clinical cases.

\section{ACKNOWLEDGMENTS}

We thank the "Coordination of Improvement of Higher Education" (CAPES) Institute for financial support, as well as all of the teachers at VH-UEL, in particular Professor Dr. Josmari Pirolo, the residents of the VH-UEL, and the Microbiology and Veterinary Clinical Pathology laboratories at VH-UEL.

\section{REFERENCES}

BAUER, A.W.; KIRBY, W.M.M.; SHERRIS, J.C. et al. Antibiotic susceptibility testing by a standardized single disk method. Am. J. Clinic Pathol., v.45, p.493496, 1996.

COGGAN, J.A. Estudo microbiológico de conteúdo intra-uterino e histopatológico de útero de cadelas com piometra e pesquisa de fatores de virulência em cepas de E. coli e o potencial risco à saúde humana. 2005. 156f. Dissertação (Mestrado em Medicina Veterinária) - Faculdade de Medicina Veterinária e Zootecnia, Universidade de São Paulo, São Paulo, 2005.
FIENI, F. Patologia de los ovários y el útero. In: WANKE, M.M.; GOBELLO, C. Reproduccion en Caninos y Felinos Domesticos. 1.ed., Buenos Aires: Ed. Inter-Médica, 2006, p.75-89.

FRANSSON, B. Systemic Inflammatory Response in Canine Pyometra: The Response to Bacterial Uterine Infection. 2003. Doctoral Thesis (Veterinaria) Swedish University of Agricultural Sciences, Uppsala, 2003.

FRANSSON, B.A.; LAGERSTEDT, A.; BERGSTROM, A. et al. C-reactive protein, tumor necrosis factor $\alpha$, and interleukin- 6 in dogs with pyometra and SIRS. J. Vet. Emerg. Crit. Care, v.17, p.373-381, 2007.

GEBHARDT, C.; HIRSCHBERGER, J.; RAU, S.; ARNDT, G.; KRAINER, K.; SCHWEIGERT, F. J.; BRUNNBERG, L.; KASPERS, B.; KOHN, B. Use of C-reactive protein to predict outcome in dogs with systemic inflammatory response syndrome or sepsis. Journal of Veterinary Emergency and Critical Care, v.19, n.5, p.450-458, 2009.

GREENE, C.E.; PRESCOTT, J.F. Streptococcal and other Gram-positive bacterial infections. In: GREENE, C.E. Infectious diseases of the dog and cat. 3.ed. Saint Louis: Saunders, 2006. p.302-315.

GUTIERREZ, G.; WULF, M.E. Lactic acidosis in sepsis: a commentary. J. Int. Care Med., v.22, p.6-16, 1996.

HAGMAN, R. New Aspects of Canine Pyometra: Studies on Epidemiology and Pathogenesis. 2004. Doctoral Thesis (Veterinaria) Swedish University of Agricultural Sciences, Uppsala, 2004.

HAGMAN, R.; LAGERSTEDT, A.; HEDHAMMAR, A.; EGENVALL, A. A breed-matched case-control study of potential risk-factors for canine pyometra. Theriogenology, v.75, p.1251-1257, 2011. 
HAGMAN, R.; REEZIGT, B.J.; LEDIN, H.B.; KARLSTAM, E. Blood lactate levels in 31 female dogs with pyometra. Acta Vet. Scand., v.9, p.51-52, 2009.

HAUPTMAN, J.V.; WALSHAW, R.; OLIVIER, N.B. Evaluation of the sensitivity and specificity of diagnostic criteria for sepsis in dogs. Vet. Surg., v.26, p.393-397, 1997.

HOLAHAN, M.L.; BROWN, A.J.; DROBATZ, K.J. The association of blood lactate concentration with outcome in dogs with idiopathic immune-mediated hemolytic anemia: 173 cases (2003-2006). J. Vet. Emerg. Critical Care., v.20, p.413-420, 2010.

HOLT, J.; KRIEG, N.; SNEATH, P. (9ED). Bergey's manual of determinative bacteriology. Williams \& Wilkins, 1994. p.186-187.

JOHNSON, C.A. Distúrbios do sistema reprodutivo In: NELSON, R.W.; COUTO, C.G. Medicina Interna de Pequenos Animais. 3.ed, Rio de Janeiro: Elsevier, 2006. p.840-844.

JOHNSTON, S.D.; KUSTRITZ, M.V.R.; OLSON, P.N.S. Canine and feline theriogenology. Philadelphia : Saunders, 2001. p.19-104.

KOLISKI, A.; CAT, I.; GIRALDI, D.J.; CAT, M.L. Lactato sérico como marcador prognóstico em crianças gravemente doentes. J. Pediatria., v.81, p.287-292, 2005.

KUPLULU, S.; VURAL, M.R.; DEMIREL, A. et al. The comparative evaluation of serum biochemical, hematological, bacteriological and clinical findings of dead and recovered bitch with pyometra in the postoperative process. Acta Vet. (Beograd)., v.59, p.193-204, 2009.

LAGUTCHIK, M.S.; OGILVIE, G.K.; HACKETT, T.B.; WINGFIELD, W.E. Increased lactate concentrations in III and injured dogs. J. Vet. Emerg. Crit. Care., v.8, p.117-127, 1998.

NATIONAL Committee for Clinical Laboratory Standards (NCCLS). 1999. Performance standards for antimicrobial disk and dilution susceptibility tests for bacteria isolated from animals - approved standard M31-A. National Committee for Clinical Laboratory Standards, Wayne, PA.
NEL, M.; LOBETTI, R.G.; KELLER, N.; THOMPSON, P.N. Prognostic value of blood lactate, blood glucose, and hematocrit in canine babesiosis. $J$. Vet. Int. Med., v.18, p.471-476, 2004.

OTTO, C.M. Sepsis in veterinary patients: what dowe knowand where canwe go? J. Vet. Emerg. Crit. Care., v.17, p.329-332, 2007.

PELANDER, L.; HAGMAN, R.; HAGGSTROM, J. Concentrations of cardiac troponin I before and after ovariohysterectomy in 46 female dogs with pyometra. Acta Vet. Scand., v.50, p.35, 2008.

PRETZER, S.D. Clinical presentation of canine pyometra and mucometra: A review. Theriogenology., v.70, p.359-363, 2008.

PURVIS, D.; KIRBY, R. Systemic inflammatory response syndrome: Septic. Vet. Clin. North Am.: Small anim. Pract., v.24, p.1225-1247, 1994.

RABELO, R.C.; ARNOLD, C.F.; ALSUA S.C. RICO Score - Classificação rápida de sobrevida em cuidados intensivos. Variáveis inter-relacionadas em cães. Rev. Clínica Vet., v.78, p.28-38, 2009.

SIQUEIRA, A.K.; RIBEIRO, M.G.; SALERNO, T. et al. Perfil de sensibilidade e multirresistência em linhagens de Escherichia coli isoladas de infecção do trato urinário, de piometra e de fezes de cães. Arq. Bras. Med. Vet. Zootec., v.60, p.1263-1266, 2008.

STEVENSON, C.K.; KIDNEY, B.A.; DUKE, T. et al. Serial blood lactate concentrations in systemically ill dogs. Vet. Clin. Pathol., v.36, p.234-239, 2007.

VOLPATO, R.; MARTINS, I.; RAMOS, R.S. et al. Imunoistoquímica de útero e cérvix de cadelas com diagnóstico de piometra. Arq. Bras. Med. Vet. Zootec., v.64, p.1109-1117, 2012.

WEISS, R.R.; CALOMENO, M.A.; SOUSA, R.S. et al. Avaliação Histológica, Hormonal e Bacteriológica da Piometra na cadela. Arch.Vet. Sci., v.9, p.81-87, 2004. 